\title{
DISTRIBUTION, PARASITOIDS AND CYCLIC APPEARANCE OF RUSSIAN WHEAT APHID DIURAPHIS NOXIA (MORDVILKO, 1913) (HEMIPTERA, APHIDIDAE) IN ALGERIA
}

\author{
MALIK LAAMARI*, SOUMIA BOUGHIDA, and HALIMA MEROUANI \\ LATPPAM Laboratory, Institute of Veterinary and Agronomic Sciences, Department of Agronomy, University of Batna, 05000, Algeria \\ *Corresponding author: laamarimalik@yahoo.fr
}

\begin{abstract}
This information on the Russian wheat aphid Diuraphis noxia (Hemiptera, Sternorrhyncha, Aphididae) in those regions of Algeria where cereals are grown is based on a nineteen year study. This revealed that this aphid is widely distributed in the high plateaus and interior plains with semi-arid climates. The mummies of this aphid found among its colonies were collected and 4 parasitoids (Hymenoptera, Braconidae, Aphidiinae) where identified. These were Diaeretiella rapae (M'Intosh), Aphidius matricariae (Haliday), Aphidius rhopalosiphi (Destefani) and Lysiphlebus testaceipes (Cresson), with D. rapae the most abundant. Moreover, this study also indicates that the cyclical appearance of this aphid is determined by the intensity of precipitation during winter and spring.
\end{abstract}

Keywords: Diuraphis noxia, distribution area, parasitoids, periodic infestation, Algeria

\section{Introduction}

The Russian wheat aphid Diuraphis noxia (Mordvilko 1913) is one of the most damaging aphid species infesting wheat and barley (Rechmany et al. 1993; Al Ayedh 2000). Its very toxic saliva causes leaves to develop longitudinal chloroses, stunts growth, impairs the quality of the grain and even causes plants to desiccate (Calhoun et al. 1991). This aphid was originally described from the Caucasus region in 1900 and probably spread to Africa from western Asia (Walters et al. 1980). D. noxia was first encountered in Ethiopia in 1973, at a time when a drought started in the northern part of the country (Haile and Megenasa 1987). This aphid was first reported in South Africa in 1978 (Miller et al. 1993). In this country, Robinson (1994) mentions that losses may amount to up to $92 \%$ of the production. In North Africa (Algeria, Morocco, Tunisia, Libya and Egypt), D. noxia was reported for the first time in 1987 (Miller et al. 1993).

In Algeria, Tahir cited by Miller et al. (1993) estimate the area of wheat infested with this aphid was about 200 ha in Sétif (eastern Algeria) in 1989. During the same year, it was reported in Sidi Bel Abbès by Maatougui in Tiaret (western Algeria) and by Mekni (Miller et al. 1993). More recently, it was reported in Constantine in 1991 on Hordeum vulgare L. and Triticum aestivum L. and in Batna in 1992 on Phalaris brachystachys Link. (Laamari 2004). Oufroukh et al. (2011) report that $D$. noxia is one of the aphids implicated in the transmission of Barley yellow dwarf virus (BYDV) in some regions of Algeria. Despite its importance, this aphid has been poorly studied in Algeria. Many aspects, including its biology, distribution, economic effect and the action of abiotic and biotic factors on this aphid are unstudied. This study was conducted in order to delimit the area of distribution of this aphid in Algeria. In addition, climate data for five years is used to determine the effect of climate on infestations of this aphid in the Batna region. Finally, the Hymenopteran parasitoids associated with this aphid in the regions of Batna, Khenchela and Oum El Bouaghi, are identified.

\section{Material and Methods}

\section{Distribution Area}

This study was carried out in the major cereal producing areas in Algeria. From thirty seven localities (Table 1), samples were collected from February till June from 1992-2009, depending on the growing season at each locality. Considering the importance of the area surveyed, the localities selected were not visited in the same year. At each locality, samples were taken from different cereal crops. The infested tillers were placed in plastic boxes already labelled and brought back to the laboratory where the numbers of aphids were counted. The GPS coordinates and altitude of each field were recorded and the distribution plotted on a map (Fig. 1).

\section{Parasitoids}

This part of the study was done in fields of cereals located in the departments of Oum El Bouaghi (locality El Harmelia), Khenchela (locality Kais) and Batna (locality Hemla). On each sampling date and from each field, twenty tillers were carefully collected at random and transported to the laboratory. Each tiller bearing colonies of living and mummified aphids was kept in a separate vial. Each vial was numbered and labelled with the date, the field and locality. The vials were inspected daily for the presence of mummies. Once they were detected, they were carefully removed from the leaves and kept individ- 
ually in small plastic boxes. A circular opening was cut into the lid of each box and covered with muslin for ventilation. Each plastic box was labelled with the number of the vial the mummy was removed from. The samples were reared in the laboratory at room temperature for 2-3 weeks, until all adult parasitoids emerged.

\section{Cyclic Appearance}

In order to determine the effect of temperature and rain fall on population fluctuations of the Russian wheat aphid, the data recorded in the Batna region (Locality
Hemla) for the years 1992, 1999, 2008, 2009 and 2010 were used. According to Miller et al. (1993) climatic conditions in winter and spring determine the levels of infestation of cereals by this aphid. For this reason, the data on temperature and rain fall for five months (January-May) of each year were taken into consideration. To follow the level of infestation by D. noxia in the Batna region, each year samples were collected from March to May in barley fields, which is the principal crop in this region. Within each field, 20 tillers were collected at random at 5 different places (total of 100 tillers per field).

Table 1 Coordinates and years of the surveys of the different localities studied.

\begin{tabular}{|c|c|c|c|c|}
\hline Departments & Locality & Altitude (m) & Lat. (N) Long. (E or O) & Years sampled \\
\hline \multirow{3}{*}{ Oum El Bouaghi } & Ain Mlila & 781 & $36.02^{\circ} \mathrm{N} 6.33^{\circ} \mathrm{E}$ & 2000,2008 \\
\hline & Ain Kercha & 807 & $35.55^{\circ} \mathrm{N} 6.40^{\circ} \mathrm{E}$ & 2008 \\
\hline & El Hermelia & 794 & $35.92^{\circ} \mathrm{N} 6.62^{\circ} \mathrm{E}$ & 2008 \\
\hline \multirow{7}{*}{ Batna } & Ain Djasser & 864 & $35.51^{\circ} \mathrm{N} 6.00^{\circ} \mathrm{E}$ & 2008 \\
\hline & Tzouket & 1547 & $35.23^{\circ} \mathrm{N} 6.25^{\circ} \mathrm{E}$ & 2008 \\
\hline & Bouhmar & 1382 & $35.26^{\circ} \mathrm{N} 6.21^{\circ} \mathrm{E}$ & 2008 \\
\hline & Hemla & 1128 & $35.32^{\circ} \mathrm{N} 6.04^{\circ} \mathrm{E}$ & 1992, 1999, 2008, 2009, 2008, 2010 \\
\hline & Batna & 1058 & $35.32^{\circ} \mathrm{N} 6.08^{\circ} \mathrm{E}$ & $1992,1993,2008$ \\
\hline & Arris & 1205 & $35.17^{\circ} \mathrm{N} 6.24^{\circ} \mathrm{E}$ & 1995, 2001, 2008 \\
\hline & El Madher & 881 & $35.63^{\circ} \mathrm{N} 6.38^{\circ} \mathrm{E}$ & 1994, 2006, 2008 \\
\hline \multirow{3}{*}{ Biskra } & El Kantara & 466 & $35.12^{\circ} \mathrm{N} 5.41^{\circ} \mathrm{E}$ & 2006,2007 \\
\hline & El Outaya & 221 & $34.97^{\circ} \mathrm{N} 5.58^{\circ} \mathrm{E}$ & 2004,2007 \\
\hline & Ain Benoui & 110 & $34.81^{\circ} \mathrm{N} 5.66^{\circ} \mathrm{E}$ & 2002,2004 \\
\hline Tebessa & Cheria & 1085 & $35.15^{\circ} \mathrm{N} 7.44^{\circ} \mathrm{E}$ & 1999 \\
\hline Tiaret & Mehdia & 910 & $35.26^{\circ} \mathrm{N} 1.46^{\circ} \mathrm{E}$ & 1999, 2002 \\
\hline Djelfa & Ain Oussara & 675 & $35.28^{\circ} \mathrm{N} 2.54^{\circ} \mathrm{E}$ & 2006 \\
\hline Saida & Youb & 636 & $34.55^{\circ} \mathrm{N} 0.10^{\circ} \mathrm{E}$ & 2004 \\
\hline \multirow{5}{*}{ Sétif } & Sétif & 1040 & $36.11^{\circ} \mathrm{N} 5.23^{\circ} \mathrm{E}$ & 2008 \\
\hline & Guellal & 902 & $36.03^{\circ} \mathrm{N} 5.33^{\circ} \mathrm{E}$ & 1995, 2000, 2004, 2005 \\
\hline & Oum Ladjoul & 905 & $35.55^{\circ} \mathrm{N} 5.54^{\circ} \mathrm{E}$ & $1995,1996,1997,1998$ \\
\hline & Hammam Sokhna & 905 & $35.58^{\circ} \mathrm{N} 5.50^{\circ} \mathrm{E}$ & 1996, 1997, 1998, 2008, 2009 \\
\hline & El Eulma & 963 & $36.16^{\circ} \mathrm{N} 5.69^{\circ} \mathrm{E}$ & 2009 \\
\hline Sidi Bel Abbès & Telagh & 888 & $34.59^{\circ} \mathrm{N} 0.29^{\circ} \mathrm{E}$ & 2006 \\
\hline Annaba & El Hadjar & 13 & $36.76^{\circ} \mathrm{N} 7.66^{\circ} \mathrm{E}$ & 2008,2009 \\
\hline Guelma & Guelma & 423 & $36.44^{\circ} \mathrm{N} 7.41^{\circ} \mathrm{E}$ & 2009 \\
\hline \multirow{2}{*}{ Constantine } & El khroub & 619 & $36.16^{\circ} \mathrm{N} 6.40^{\circ} \mathrm{E}$ & 2007, 2008, 2009 \\
\hline & Ain Abid & 876 & $36.13^{\circ} \mathrm{N} 6.57^{\circ} \mathrm{E}$ & 1995 \\
\hline M'sila & Megra & 565 & $35.36^{\circ} \mathrm{N} 5.5^{\circ} \mathrm{E}$ & 1999 \\
\hline \multirow{2}{*}{ Bourdj Bou-Arreridj } & Ras El Oued & 1086 & $35.54^{\circ} \mathrm{N} 4.58^{\circ} \mathrm{E}$ & 1992,1999 \\
\hline & Bordj Ghedir & 1271 & $35.53^{\circ} \mathrm{N} 4.56^{\circ} \mathrm{E}$ & 1992,1998 \\
\hline El Oued & Hassi Khelifa & 51 & $33.56^{\circ} \mathrm{N} 6.99^{\circ} \mathrm{E}$ & 2006 \\
\hline Taref & El Kous & 5 & $36.79^{\circ} \mathrm{N} 7.85^{\circ} \mathrm{E}$ & 2005,2009 \\
\hline \multirow{2}{*}{ Khenchela } & Kais & 1193 & $35.25^{\circ} \mathrm{N} 7.07^{\circ} \mathrm{E}$ & $1994,2001,2008$ \\
\hline & Bouhmama & 1157 & $35.19^{\circ} \mathrm{N} 6.45^{\circ} \mathrm{E}$ & 1996, 2004 \\
\hline \multirow{2}{*}{ Mila } & Chelghoum El Aid & 766 & $36.11^{\circ} \mathrm{N} 6.13^{\circ} \mathrm{E}$ & 1997, 2008 \\
\hline & Teleghma & 782 & $36.4^{\circ} \mathrm{N} 6.20^{\circ} \mathrm{E}$ & 2008 \\
\hline
\end{tabular}




\section{Results}

\section{Distribution Area}

Colonies of the Russian wheat aphid were found in several fields of durum wheat, common wheat, barley and oats at 34 localities in 15 Departments (Fig. 1). It is completely absent in the departments Taref, Annaba and Guelma.

\section{Parasitoids}

In total, 56 specimens of Hymenopteran parasitoids were collected and identified. Four parasitoids emerged from the mummies of Russian wheat aphid collected from the localities at El Hermelia (Oum El Bouaghi), Kais (Khenchela) and Hemla (Batna) in 2008 (Table 2).

\section{Cyclic Appearance}

At the different localities surveyed in 2009 and 2010, D. noxia was not present in cereal fields that are usually moderately or heavily infested. The same phenomenon is reported in some European countries, particularly Albania by Stary in 2008 (personal communication, 2011). Compared to previous years, 2009 was exceptional, especially the spring. Based on the data in table 3 , it appears that the precipitation recorded during the first 5 months of $2009(245.6 \mathrm{~mm})$ and during the months of January $(67.9 \mathrm{~mm})$ and April $(75.1 \mathrm{~mm})$ was higher than in other years (Table 3$)$. Average maximum $\left(16.6^{\circ} \mathrm{C}\right)$ and minimum $\left(3.4^{\circ} \mathrm{C}\right)$ temperatures and the average temperature $\left(9.9^{\circ} \mathrm{C}\right)$ in 2009 are very similar to other years. It is noteworthy that the average temperatures in April $\left(11^{\circ} \mathrm{C}\right)$ and May $\left(17.5^{\circ} \mathrm{C}\right)$ in 2009 were slightly lower than in 1999 and 2008.

\section{Discussion}

The Russian wheat aphid, D. noxia, was recorded infesting cereals on the high plateaus and plains in the interior of Algeria. All these regions have a semi-arid climate (cold in winter and hot and dry in summer). The temperature variation is important and rain very irregular. All these regions are located at altitudes between $565 \mathrm{~m}$ (M'sila) and $1547 \mathrm{~m}$ (Batna). According to Stary and Lukasova (2002) dense colonies of D. noxia are usually recorded on cereals grown in the highest regions. It should be noted that over several years alatae were trapped in barley fields at El Oued and Biskra (Algerian Sahara). These regions are in an arid bioclimatic area and at mean altitude of $51 \mathrm{~m}$. In addition, surveys carried out in coastal areas, characterized by a humid and sub-humid climate revealed the complete absence of this aphid. Indeed Basky (2003) mentions that the high relative humidity is not favourable for the development of the Russian aphid.

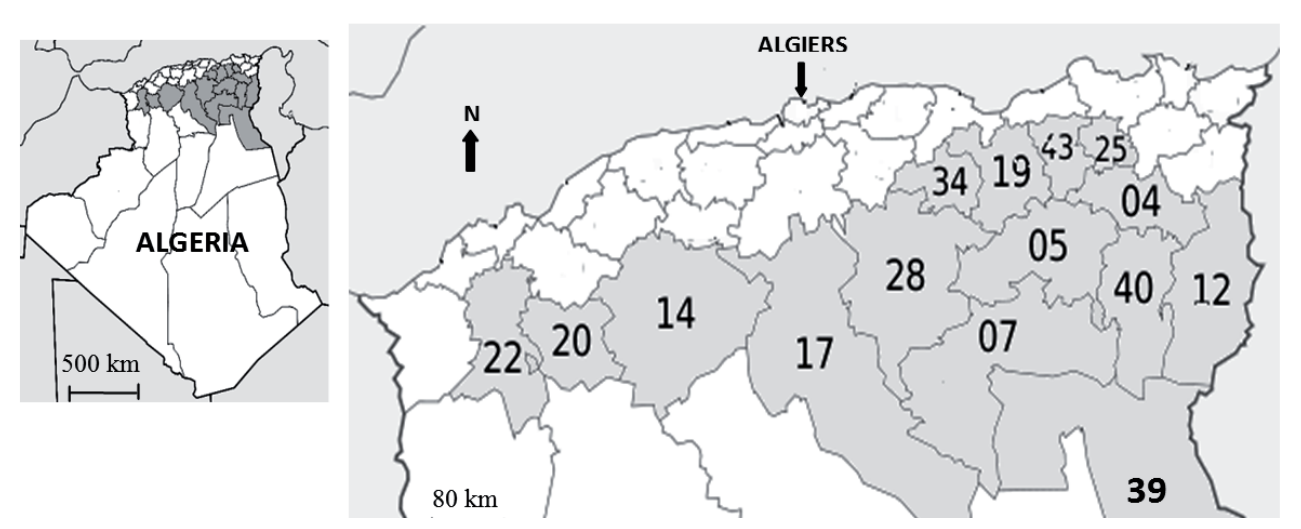

Fig. 1 Distribution area of Diuraphis noxia in Algeria. Numbers correspond to administrative codes of departments where Russian wheat aphid is present, 04, Oum El Bouaghi, 05, Batna, 07, Biskra, 12, Tebessa, 14, Tiaret, 17, Djelfa, 19, Sétif, 20, Saida, 22, Sidi Bel Abbès, 25, Constantine, 28, M'sila, 34, Bordj Bou Arreridj, 39, El Oued, 40, Khenchela, 43, Mila.

Table 2 Numbers of parasitoids reared from mummies that developed in colonies of Diuraphis noxia collected at different localities in 2008.

\begin{tabular}{lccccc}
\hline Localities & Host plants & Diaeretiella rapae & $\begin{array}{c}\text { Aphidius } \\
\text { matricariae }\end{array}$ & $\begin{array}{c}\text { Aphidius } \\
\text { Rhopalosiphi }\end{array}$ & $\begin{array}{c}\text { Lysiphlebus } \\
\text { testaceipes }\end{array}$ \\
\hline Hemla (Batna) & Hordeum vulgare & 7 & 0 & 0 & $\mathbf{7}$ \\
& H. vulgare & 14 & 0 & 4 & 10 \\
El Hermelia & Avena sativa & 4 & 0 & 0 & 0 \\
(Oum El Bouaghi) & Triticum aestivum & 6 & 0 & $\mathbf{4}$ & 0 \\
\hline Kais (Khenchela) & H. vulgare & 0 & 5 & $\mathbf{1 2}$ & $\mathbf{5}$ \\
\hline & Total & $\mathbf{3 1}$ & $\mathbf{5}$ & $\mathbf{1 0}$ & $\mathbf{5}$
\end{tabular}


From mummies found in colonies of this aphid, four primary parasitoids emerged (Table 1). Among the parasitoids found, Aphidius matricariae was introduced into South Africa from Turkey to control populations of $D$. noxia (Berner 2006). Compared to previous species, $D i$ aeretiella rapae is more common. It was found at several localities in all cereal crops. It is considered to be the most important parasitoid of the Russian aphid in central Asia, east and western Europe, the Mediterranean region and Northern and Southern Africa (Kovalev et al. 1991; Bernal and Gonzalez 1997). Even in Iran, Rakhshani et al. (2008) indicates that the parasitoid D. rapae is mostly associated with $D$. noxia. These authors also mention that this parasitoid is used as a biological control agent against this pest in Iran. Lysiphlebus testaceipes emerged from the mummies collected from barley at Oum El Bouaghi. It was less abundant than the three previously mentioned parasitoids. Despite the absence of chemical treatments, the number of parasitoids is very low. Compared to other cereal aphids, the Russian wheat aphid prefers to live inside rolled up leaves. Indeed, Berner (2006) report that this aphid prefers to feed at the base of rolled leaves

Table 3 The temperatures $\left({ }^{\circ} \mathrm{C}\right)$, precipitation $(\mathrm{mm})$ and level of infestation (aphid/tiller) by Diuraphis noxia recorded in five years in barley fields in Batna (locality Hemla).

\begin{tabular}{|c|c|c|c|c|c|c|}
\hline \multirow{2}{*}{ Years } & \multirow{2}{*}{ Months } & \multicolumn{3}{|c|}{ Temperatures } & \multirow{2}{*}{ Precipitation } & \multirow{2}{*}{ Level of infestation } \\
\hline & & T. Max. & T. min. & T. Mean & & \\
\hline \multirow{7}{*}{1992} & January & 10.2 & -2.8 & 3.7 & 28.2 & \multirow{7}{*}{3} \\
\hline & February & 12.9 & 4.5 & 8.9 & 22.7 & \\
\hline & March & 13.7 & 2.9 & 8.3 & 42.7 & \\
\hline & April & 17.5 & 4.7 & 11.1 & 21.3 & \\
\hline & May & 23.0 & 8.8 & 15.9 & 81.7 & \\
\hline & Mean & 15.5 & 3.6 & 9.6 & 39.3 & \\
\hline & \multicolumn{4}{|c|}{ Total } & 196.6 & \\
\hline \multirow{7}{*}{1999} & January & 12.0 & 0.4 & 6.2 & 41.9 & \multirow{6}{*}{18} \\
\hline & February & 10.5 & -0.7 & 4.9 & 8.1 & \\
\hline & March & 16.7 & 1.9 & 9.3 & 28.9 & \\
\hline & April & 22.3 & 5.5 & 13.9 & 17.7 & \\
\hline & May & 30.7 & 12.9 & 21.8 & 6.2 & \\
\hline & Mean & 18.4 & 4.0 & 11.2 & 20.6 & \\
\hline & \multicolumn{4}{|c|}{ Total } & 102.8 & \multirow{8}{*}{12} \\
\hline \multirow{7}{*}{2008} & January & 13.7 & 0.0 & 6.7 & 9.6 & \\
\hline & February & 15.3 & 0.1 & 7.7 & 2.3 & \\
\hline & March & 16.8 & 2.7 & 9.7 & 39.3 & \\
\hline & April & 22.7 & 5.4 & 14.1 & 3.3 & \\
\hline & May & 26.4 & 11.8 & 19.1 & 107.0 & \\
\hline & Mean & 18.9 & 4.0 & 11.5 & 32.3 & \\
\hline & \multicolumn{4}{|c|}{ Total } & 161.5 & \\
\hline \multirow{7}{*}{2009} & January & 11.2 & 1.6 & 6.2 & 67.9 & \multirow{7}{*}{0} \\
\hline & February & 12.2 & 0.4 & 6.0 & 21.4 & \\
\hline & March & 16.7 & 1.7 & 9.1 & 27.9 & \\
\hline & April & 17.0 & 4.6 & 11.0 & 75.1 & \\
\hline & May & 25.8 & 8.5 & 17.5 & 53.3 & \\
\hline & Mean & 16.6 & 3.4 & 9.9 & 49.1 & \\
\hline & \multicolumn{4}{|c|}{ Total } & 245.6 & \\
\hline \multirow{7}{*}{2009} & January & 13.3 & 2.1 & 7.7 & 36.2 & \multirow{7}{*}{0} \\
\hline & February & 15.7 & 3.5 & 9.6 & 15.7 & \\
\hline & March & 18.2 & 5.1 & 11.7 & 28.4 & \\
\hline & April & 21.5 & 7.9 & 14.7 & 56.1 & \\
\hline & May & 23.2 & 8.6 & 15.9 & 37.7 & \\
\hline & Mean & 18.6 & 5.4 & 11.92 & 34.8 & \\
\hline & \multicolumn{4}{|c|}{ Total } & 174.0 & \\
\hline
\end{tabular}

(Data from the meteorological station at Batna, $821.29 \mathrm{~m}$.) 
where it is protected from natural enemies. In addition, to mortality due to hyper-parasitism, many mummies are trapped inside tightly rolled leaves. Crushed or deformed mummies were frequently recorded in colonies of this aphid.

Monitoring the level of infestation of barley in the Batna region for five years has shown that this aphid is very sensitive to climatic factors. In 2009, heavy rainfall recorded in winter and spring was followed by a major reduction in the abundance of this aphid. Miller et al. (1993) report that the losses of yield caused by D. noxia are very high during periods of prolonged drought. In terms of temperature, there were no important differences between the five years of the study. It seems that, Russian wheat aphid can tolerate low winter temperatures. According to Kiplagat (2005), this aphid tolerates temperatures down to $-27^{\circ} \mathrm{C}$. Moreover, Basky (1993) reports that in summer time, this aphid can survive a temperature of $30^{\circ} \mathrm{C}$. According to Ashfaq et al. (2007) the optimum development of this aphid occurs between 13.7 and $30.3{ }^{\circ} \mathrm{C}$. Despite this, 2010 was less rainy than 2009 , but no aphids were recorded on barley. It is possible that it needs several favourable years to achieve high levels of infestation in cereal crops.

\section{Conclusions}

Surveys carried out over 19 years (1992-2010) revealed the presence of Diuraphis noxia on durum wheat, common wheat, barley and oats at 34 localities in 15 Algerian departments. This aphid occurs mainly in semi-arid areas with cold winters. In addition, the mummies found in colonies of this aphid were produced by four Hymenopteran parasitoids (Aphidius matricariae, Aphidius rhopalosiphi, Diaeretiella rapae and Lysiphlebus testaceipes). Diaeretiella rapae was the most common parasitoid. It was found in all the departments monitored for parasitoids. The study of the infestation level of barley in the Batna region over a five year period revealed that the appearance of this aphid is cyclical. Apparently, the amount of rainfall recorded in the spring of 2009, particularly during the months of February and April resulted a significant reduction in the abundance of this aphid.

\section{REFERENCES}

Al-Ayedh HY (2000) Field biology of Russian wheat aphid, Diuraphis noxia (Mordvilko) (Homoptera: Aphididae) on wheat's differing in categories of resistance. Doctorate Thesis, University of Bio-agricultural Sciences and Pest Management, Colorado, USA.
Ashfaq M, Iqbal J, Ali A, Farooq U (2007) Role of abiotic factors in population fluctuation of aphids on wheat. Pakistan Entomol 29: $117-122$

Basky Z (1993) Incidence and population fluctuation of Diuraphis noxia in Hungary. Crop Prot 12: 205-209.

Basky Z (2003) Biotypic and pest status differences between Hungarian and South African populations of Russian wheat aphid, Diuraphis noxia (Kurdjumov) (Homoptera: Aphididae). Pest Manag Sc 59: 1152-1158.

Bernal J, Gonzalez D (1997) Reproduction of Diaeretiella rapae on Russian Wheat Aphid hosts at different temperatures. Entomol Exp Appl 82: 159-166.

Berner J (2006) Biochemistry of Russian Wheat Aphid resistance in Wheat: Involvement of Lipid-like products. Doctorate Thesis, University of the Free State, Bloemfontein, South Africa.

Calhoun DS, Burnett PA, Robinson J, Vivar HE, Gilchrist L (1991) Field resistance to the Russian Wheat aphid in Barley: II. Yield Assessment. Crop Sci 31: 1468-1472.

Haile A, Megenasa T (1987) Survey of aphids on barley in parts of Shewa, Welo and Tigrai, Ethiopia. Ethiopian J Agr Sci 3: 39-53.

Kiplagat OK (2005) The Russian Wheat Aphid (Diuraphis noxia Mord.) damage on Kenyan wheat (Triticum aestivum L.) Varieties and possible control through resistance breeding. Doctorate Thesis, University Aula of Wageningen, Kenya.

Kovalev OV, Poprawski TJ, Stekolshchikov AV, Vereshchagina AB, Grandrabur SA (1991) Diuraphis aizenberg (Homoptera: Aphididae): key to apterous viviparous females, and a review of Russian language literature on the natural history of Diuraphis noxia (Kurdjumov 1913). J Appl Entom 112: 425-436.

Laamari M (2004) Etude éco-biologique des pucerons des cultures dans quelques localités de l'Est Algérien. Thèse Doctorat, Institut National d'Agronomie, Alger, Algérie.

Miller RH, Tanigohi LK, Buschman LL, Kornosor S (1993) Distribution and ecology of Russian wheat aphid, Diuraphis noxia Mordvilko (Homoptera: Aphididae) in western Asia and northern Africa. Arab J Plant Prot 11: 45-52.

Oufroukh A, Khelifi D, Dehimat L (2011) Contribution à létude des maladies foliaires des céréales "approche à létude épidémiologique et identification de la jaunisse nanisante de lorge dans les céréales d'hiver dans les régions de l'Est algérien". Sci Tech C 33: 53-61.

Rakhshani E, Tomanovic Z, Starý P, Talebi AA, Kavallieratos NG, Zamani AA, Stamenkovic S (2008) Distribution and diversity of wheat aphid parasitoids (Hymenoptera: Braconidae: Aphidiinae) in Iran. Eur J Entomol 105: 863-870.

Rechmany N, Miller RH, Traboulsi AF, Kfoury L (1993) The Russian Wheat Aphid Diuraphis noxia (Kurdjmov) (Homoptera: Aphididae) and its Natural Enemies in Northern Syria. Arab J Plant Protect 11: 92-99.

Robinson J (1994) Identification and characterization of resistance to the Russian wheat aphid in small-grain cereals: investigation at CIMMYT, 1991-92. CIMMYT, Mexico.

Stary P, Lukasova H (2002) Increase of Russian wheat aphid, Diuraphis noxia (Kurdj.) in hot and dry weather (2000) (Hom., Aphididae). J Pest Sci 75: 6-10.

Walters MC, Penn F, Du Toit F, Botha TC, Aalbersberg K, Hewitt PH, Boodryk KW (1980) The Russian wheat aphid. Farm South Africa 3: 1-6. 